DOI: 10.1515/auseur-2016-0008

\title{
Linguistic Justice, van Parijs, and Esperanto
}

\author{
Federico GOBBO \\ Universities of Amsterdam / Milano-Bicocca / Torino \\ F.Gobbo@uva.nl
}

\begin{abstract}
In the European and world-wide scenario of linguistic justice offered by van Parijs (2011), it is argued that we need one lingua franca only and that the only suitable candidate is English. In order to sustain his argument, the author has to reject three known alternatives against the English-only scenario. The second alternative is Esperanto. Van Parijs argues that there are some inner defects in the Esperanto language, and therefore Esperanto is not suitable for the role of world-wide lingua franca. This paper offers counterarguments based on the evidence of facts, showing that if nowadays Esperanto is only a lesser-used language the reason is not in the inner traits of the language, rather in geopolitical decisions. I argue that in the most probable global scenario English still plays the actual major role, but along with other cultural languages being regional lingua francas.
\end{abstract}

Keywords: linguistic justice, Esperanto, political neutrality, cultural languages, regional lingua francas

The first time I met Philippe van Parijs we were in Vilnius, Lithuania. It was 2005, and the occasion was the Nitobe Symposium 4, a conference devoted to delve into the aspects of the language politics of enlargement of the European Union. Van Parijs was an invited speaker in Vilnius. That conference series is organized by the Centre for Research and Documentation on World Language Problems, with the fundings of the Esperantic Studies Foundation. The working languages were English, Esperanto, and Lithuanian. When he published his very influential book on linguistic justice (van Parijs 2011), obviously, he had already been well-informed about Esperanto for at least six years.

For this reason, when I read his book, finding a part about Esperanto was not a surprise. But it was a surprise to me finding inaccuracies and even untrue statements. I take the occasion here to put forward my counterarguments. I will focus myself on the arguments against Esperanto published in van Parijs (2011), assuming that his position on the topic has not changed since then.

The number of pages devoted to Esperanto are only seven in total (39-46), in the Appendix after the first chapter. There, readers can read the counterarguments to 
the central tenet of the whole book - the need of English as the only lingua franca of the planet. The Appendix shows the pars destruens of the three alternatives and crucially sets the ground to all the argumentation pro English presented in the rest of the book. Esperanto is the second alternative.

First of all, there is a historical inaccuracy about the relation between Esperanto and the League of Nations. That language was never directly proposed as a working language of the League unlike what is stated in the book. It is true that a report written by Edmond Privat was submitted in 1921 (and not 1923 unlike what is stated in the book) by Dr Nitobe to the attention of the League. That report illustrated the achievement of Esperanto since then. Nitobe was the leader of the Japanese delegation to the League, born in a samurai family (from Japanese nobility) from Honshu, the main island of Japan. Raised as a Christian, he then became a Friend (Quaker). In 1921, Communist parties were founded in many parts of Europe: among others, in France, Italy, and Spain. The leftist wing in the Esperanto Movement was at its acme. Many intellectuals associated Esperanto with the Soviet revolution. Nitobe checked in person that the Esperanto movement was not necessarily pro-Communist, participating in the World Esperanto Congress in Prague in 1921. Then, he decided to bring that report to the League. Because of the fierce opposition by France, any scenario of having Esperanto as a working language turned out to be impossible before any proposal would have been made. Ironically enough, at the same time, France accepted that the English versions of the documents produced by the League were equally valid as the French ones. In fear of Esperanto, French lost the monopoly of the international language of diplomacy, admitting English in the club.

This story tells us a simple but seldom admitted true: the main reason of the fact that Esperanto is not a widely recognized international language but rather the language of a minority of enthusiasts is political. This was true in the 1920s just as nowadays, almost one century later. At that time, the French linguist Antoine Meillet - briefly mentioned on page 39 - said: every theoretical discussion is in vain, Esperanto works. Van Parijs knows very well that Esperanto works, so the dismissal of the alternative to his English-only-lingua-franca scenario relies on different pillars. 'The two key advantages [Esperanto] claims are neutrality and simplicity', argues the author, then attacking these 'claims'. In the sequel, I will proceed with the illustration of the arguments by the author, along with my counterarguments.

The first argument is neutrality: 'Esperanto is very far from being neutral in the demanding sense of being equidistant from all existing languages.' But the truth is that no language can be equidistant from all the others because such an equidistance simply does not exist. A language was even planned following the idea that a 'learnability score' depends on the frequency of sounds appearing in a given word in different natural languages. The name of this almost forgotten rival of Esperanto 
is Loglan. It is known among the specialists for being the most spectacular failure in the whole history of languages planned for serious purposes. For the interested reader, Chapter 19 of Okrent (2010) tells this story with a good accuracy.

But a good question is why such feature of equidistance should be a prerequisite. In my understanding, the author has two ideas in mind. First, he thinks that this is crucial because his route for linguistic justice passes through one single lingua franca for Europe and for the world. Second, he is convinced that equidistance is a measure of neutrality in the sense of fair learnability. The second idea has neither theoretical nor empirical evidence. The structural distance between two languages is certainly one of the factors for assessing the learnability of the target language, but it is by no means the main factor. Extralinguistic variables, such as concrete needs, quantity of exposure, attitudes of the learner towards the target languages - and, of course, the political power associated with the target language -, play an important role. In many cases, they stand for more than the structural features of the language. For this reason, neutrality in this sense of fair learnability cannot be measured for any language.

Turning back to the first idea, let us accept for the moment - for the sake of the argument - that only one lingua franca is the desideratum for Europe and the world; let us call it the 'one lingua franca scenario'. If this were the case, clearly Esperanto, being a contact language (in the sense of Lindstedt 2009), is more respectful than English out of the variety of languages in the world. The phonological system of Esperanto, with its five Mediterranean vowels (Wells 1989), such as Croatian and a Germanic-Slavic consonant system (visible especially in clusters such as akvo for 'water'), is mastered by second-language learners far easier than that of English, which is known to be incredibly rich and complex. Not to mention the distance between the speech and the writing system of English, which is periodically challenged by proposals for spelling reforms, doomed to failure. The writing system of Esperanto is very respectful of its phonology, and a lot of its letters coincide with the corresponding IPA symbols. The morphology is productive and incredibly regular, compared to any natural language. Its agglutinative strategy resembles languages such as Hungarian, Finnish, or Turkish. Van Parijs subsumes this argument pro Esperanto under the rubric 'simplicity'. The morphology permits the construction of a dictionary comparable to major European languages (approximately 120,000 lexical entries) with only 16,000 radicals and twenty or so derivational morphemes (Gledhill 2000). There is no need 'to beef up its lexical stock massively', as claimed by the author. The language as it is right now is already suitable for most contexts. In the one lingua franca scenario (which I accept only for the sake of the argument), Esperanto would be far more acceptable for non-Europeans than English.

Unlike what van Parijs said, Esperanto is neutral enough to respect the linguistic and cultural habits of European citizens, regardless if they come from 
Romance, Germanic, or Slavic origins. The lexicon is more Western European, but the underlying structure is more Eastern European (Lindstedt 2009). This is a good compromise. Moreover, its agglutinative morphology was used for teaching foreign languages to Hungarians using Esperanto as a facilitator. It is without doubt more respectful than English, which is a Germanic language with a lot of Latin and Romance words in it, but unbalanced in favour of the Northern-Western European habits. The Esperanto European scenario would be a concrete motivation for, let us say, Chinese people for learning the language - regardless their level of English.

Apparently, van Parijs admits only one lingua franca for Europe and the world. But there is a point in which the author contradicts himself. Let us consider Indians, Nigerians, South Africans, or Chinese, argues van Parijs, who already invested time, money, and energy to master English: why should they be willing to learn another European-based language? In saying this, the author admits that more than one lingua franca is possible.

Unlike van Parijs, I do not believe that one lingua franca is enough for the world. The world is not flat. Kultursprachen, cultural languages, usually play the role of vehicular languages in definite areas. Think, for instance, of Arabic and Swahili in Africa, Spanish and Portuguese in South America, Chinese in China. Most probably, the more we will move across the globe, the more lingua francas we will need. In history, international languages were never decided democratically among the nations, rather they were pushed forward by strong political powers. I already presented elsewhere (Gobbo 2005) different scenarios for the language politics of the European Union, arguing that Esperanto is the most suitable candidate for playing the role of the second language for European citizens if the European Union became a confederation or a federation of states. Let us call it the 'European Esperanto scenario'. Then, van Parijs' argument against Esperanto based on the weakness of a bottom-up, voluntary-based movement also fails. The 'European Esperanto scenario' would counterbalance the tremendous impact of English as the main representative of the American way of life, proposing an alternative European dream to the American dream (Gobbo 2005).

A 'more modest sense' (p. 41) of neutrality is the fact that Esperanto 'needs to be learned by everybody'. This is simply false as Esperantists do exist. Esperanto is a unique case in history because a stable community of practice formed around it at the end of the XIX century and still lives in spite of two world wars - during the Second World War, it was explicitly persecuted. Unlike the speech communities of natural languages, which are defined by extra-linguistic sociological traits, such as ethnicity, territory, religion, and cultural habits, the community of practice (in the sense of Eckert 2006) of Esperanto is defined by a shared practice and the meta-reasoning over the practice itself: this practice is exactly the language. The colour of your skin, your social class, income, origins, and political ideas do not matter. You will be automatically part of the community of practice of Esperanto. 
The language is the product of its past and present speakers. They always reshape the language with their cultural products, most notably literature. William Auld, a Scottish poet in Esperanto, was a candidate for the Nobel Prize in Literature in 1999, 2004, and 2006. The presence of the Akademio de Esperanto, the linguistic authority is similar to the Italian Accademia della Crusca. The reality of Esperanto is that of a living language.

On the one hand, Van Parijs seems to admit that Esperanto is a non-ethnic language, and therefore it does not give unfair advantage to any group of native speakers because 'it does not belong to any particular people, to any community of native speakers'. On the other hand, he argues that 'it is no longer strictly true that it is no one's mother tongue', and therefore it is no more neutral. But this is not the case. The fact that Esperanto is spoken in families is a proof of its language vitality, not a barrier to its ethnic neutrality. Lindstedt (2010), one of the leading scholars in the study of the use of Esperanto in multilingual families, shows that 'native' or L1 speakers of Esperanto, unlike the situation of many other languages, do not have a special variety which is considered more prestigious than all the others. Mainly, this happens because there is no Sprachraum, i.e. proper linguistic space, of Esperanto: it is a stateless language, without territory. Moreover, there is no monolingual Esperanto speaker, and most probably there will never exist one. The counterargument to my defence is quite obvious. Let us reprise, for the sake of the argument, the European Esperanto scenario. There, the European Union is opportunely transformed into a confederation (like Switzerland) or a federation (like the United States), which, by the way, was what Zamenhof, the founder of Esperanto, believed in (Zamenhof 1915). After one generation, a process of nativization would occur, similar to what happened to Modern Hebrew at the time of the establishment of the state of Israel. Here, van Parijs tries to demolish the scenario with an argument without any empirical evidence: 'once turned into a really living language (...) the longer, more regular forms [will be] gradually driven into obsolescence by the shorter and less regular ones.' The truth is that nobody knows what would happen from a linguistic point of view, as we have no cases in history similar to the European Esperanto scenario.

The European Esperantophones would be more equal than the others paraphrasing Orwell -, and therefore the language would be no more politically neutral. Van Parijs rhetorically asks: 'would their language [Esperanto] retain its flavour and their community retain its warmth once appropriated by capitalists and bureaucrats?' (p. 46). I can add a stronger example. Think of the case of a European army speaking in Esperanto. For the majority of Esperantophones, Esperanto is par excellence the language of peace (Lins 2000): the idea of an army going to war shouting in Esperanto is simply repugnant.

In my view, the argument of the lack of political neutrality in any scenario where Esperanto is widely used in a Sprachraum is the only one solid and 
incontrovertible. Are the Esperantists ready to make such a jump, dismissing the idea of political neutrality, which is at the base of their ideology since the beginning (Sikosek 2006)? It is important to underline the fact that this is the only argument of van Parijs that has no relation with the language in itself. Esperanto, as a language, is ready to make the jump. For decades. But the majority of Esperantists are probably not. Also, Europeans themselves do not believe this European Esperanto dream. Unfortunately, the European Union is associated in our daily lives with banks and capitalists much more than with democracy and opportunities of growth.

I am convinced, as van Parijs is, that Europe will not go towards Esperanto but towards English (Gobbo 2015). But, for purely political reasons, not because of claimed defects of Esperanto. What divides us is the consideration of this scenario under the perspective of linguistic justice: for me, such a scenario is clearly linguistically unjust and totally unfair, but the most likely. Europe will not play a leading geopolitical role and linguistic justice for the world will not be achieved.

The research leading to these results received funding from the European Union's Seventh Framework Programme (FP7/2007-2013) under Grant Agreement No 613344.

\section{References}

ECKERT, Penelope. 2006. Communities of Practice. Encyclopedia of Language and Linguistics. Elsevier.

GLEDHILL, Christopher. 2000. The Grammar of Esperanto. A Corpus-Based Description. Munich: Lincom Europa.

GOBBO, Federico. 2005. The European Union's Need for an International Auxiliary Language. Journal of Universal Language 6: 1-28.

2015. Interlinguïstiek, een vak voor meertaligheid. Interlingvistiko, fako por multlingveco. Interlinguistics, a Discipline for Multilingualism. Oratie 532, verschenen in de oratiereeks van de Universiteit van Amsterdam op vrijdag 13 maart 2015. Amsterdam University Press.

LINDSTEDT, Jouko. 2009. Esperanto: an Eastern European Contact Language? In: VOSS, Christian-NAGÓRKO, Alicja (eds), Die Europäizität der Slawia oder dies Slawizität Europas. Ein Beitrag der kultur- und sprachrelativistischen Linguistik (Studies on Language and Culture in Central and Eastern Europe, 2). Munich-Berlin: Otto Sagner.

2010. Esperanto as a Family Language. In: DERVIN, F. (ed.), Lingua francas. La véhicularité linguistique pour vivre, travailler et étudier. L'Harmattan, 69-80. 
LINS, Ulrich. 2000. The Work of the Universal Esperanto Association for a More Peaceful World. Esperanto Documents 45 A. Rotterdam: Universala EsperantoAsocio.

OKRENT, Arika. 2010. In the Land of Invented Languages. Spiegel \& Grau.

SIKOSEK, Marcus. 2006. Die neutrale Sprache: Eine politische Geschichte des Esperanto-Weltbundes. Bydgoszcz: Skonpres.

VAN PARIJS, Philippe. 2011. Linguistic Justice for Europe and for the World. Oxford University Press.

WELLS, John. 1989. Lingvistikaj aspektoj de Esperanto. Rotterdam: Universala Esperanto-Asocio.

ZAMENHOF, Ludwik Lejzer. 1915. Alvoko al la diplomatoj. Appeal to the diplomats. The British Esperantist 123: 51-55. 